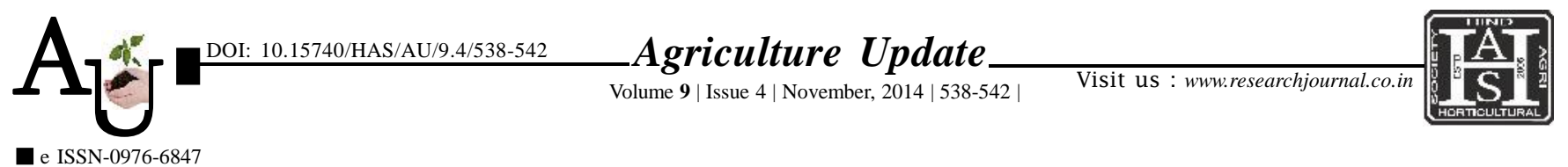

\title{
Research Article Perception and constraints in adoption of soil and water conservation practices among the Sujala Watershed Project beneficiaries of Northern Karnataka
}

Article Chronicle :

Received :

28.07.2014;

Revised :

30.09.2014;

Accepted :

11.10.2014

Key Words :

Constraints,

Karnataka,

Perception, Soil,

Water conservation,

Sujala Watershed

Project
Author for correspondence :

\section{SHREESHAIL}

RUDRAPUR

Department of

Agricultural Economics,

College of Agriculture,

University of Agricultural

Sciences, DHARWAD

(KARNATAKA) INDIA

Email:shree4476@

gmail.com

See end of the article for

authors' affiliations

\section{MITHUN P. KUDACHI, A. BHEEMAPPA, SHREESHAIL RUDRAPUR AND ANIL BIRADAR}

SUMMARY : The study was conducted during 2012-2013 in the Sujala Watershed Project implemented in Haveri and Dharwad districts of Karnataka state. Sample consisting of 80 beneficiaries of project area and 80 nonbeneficiaries were personally interviewed through well structured interview schedule. The results revealed that high perception about the usefulness and appropriateness was noticed with more number of beneficiaries $(56.25 \%)$ as compared to non-beneficiaries (40.00\%). The usefulness of nala bund, contour bund and contour strip was highly perceived by beneficiaries $(97.50 \%, 85.00 \%$ and $77.50 \%$, respectively) than non-beneficiaries $(81.25 \%$, $58.75 \%$ and $61.25 \%$, respectively). Similarly, appropriateness of constructing check dam, nala bund and dugout was highly perceived by beneficiaries $(91.25 \%, 85.00 \%$ and $82.50 \%$, respectively) as compared to non-beneficiaries $(42.50 \%, 58.75 \%$ and $57.50 \%$, respectively). Non - availability of suitable implements was expressed by 63.75 per cent non-beneficiaries and 48.75 per cent beneficiaries. Similarly, lack of technical guidance and training was observed with more of non-beneficiaries ( $58.75 \%$ and $56.25 \%$, respectively) as compared to beneficiaries (35.00\% and $31.25 \%$, respectively).

How to cite this article : Kudachi, Mithun P., Bheemappa, A., Rudrapur, Shreeshail and Biradar, Anil (2014). Perception and constraints in adoption of soil and water conservation practices among the Sujala Watershed Project beneficiaries of Northern Karnataka. Agric. Update, 9(4): 538-542. 